\title{
AMELIORATIVE EFFECT OF SIDA CORDIFOLIA L. AGAINST SCOPOLAMINE-INDUCED COGNITIVE DEFICIT MICE MODEL
}

\author{
NAVNEET KHURANA ${ }^{1}$, NEHA SHARMA ${ }^{1 *}$, SHAILENDRA PATIL ${ }^{2}$, ASMITA GAJBHIYE ${ }^{3}$
}

\begin{abstract}
${ }^{1}$ Department of Pharmacology, School of Pharmaceutical Sciences, Lovely Professional University, Phagwara, Punjab, India. ${ }^{2}$ Department of Pharmacy, Sagar Institute of Pharmaceutical Sciences, Sagar, Madhya Pradesh, India. ${ }^{3}$ Department of Pharmaceutical Sciences, Dr. H. S. Gour University, Sagar, Madhya Pradesh, India. Email: c4nehagautam@gmail.com
\end{abstract}

Received 14 July 2017, Revised and Accepted 25 July 2017

ABSTRACT

Objective: In this study, ameliorative effect of aqueous extracts of Sida cordifolia and hydroethanolic extracts of S. cordifolia L. (AESC and EESC, respectively) was evaluated against scopolamine (Sco)-induced amnesia in mice. S. cordifolia L. is a well-know Ayurvedic plant which has been administered anciently for various nervous disorders including loss of memory. Female Swiss albino mice were used for Sco-induced amnesia model and acute toxicity study.

Methods: Acute toxicity study was carried out to select safe and effective doses (50, 100 and $250 \mathrm{mg} / \mathrm{kg}$; p.o.) of AESC and EESC for further pharmacological evaluation. The AESC and EESC at selected doses and donepezil (Dpl) ( $5 \mathrm{mg} / \mathrm{kg}$; p.o.) were administered to different groups for consecutive 15 days. On $15^{\text {th }}$ day of treatment, Sco $(0.4 \mathrm{mg} / \mathrm{kg}$, intraperitoneally) was administered to different groups for induction of amnesia. Mice were subjected to transfer latency (TL) and step down latency (SDL) tests on the $16^{\text {th }}$ day to evaluate the effect of AESC and EESC on memory.

Results: Sco treatment caused a significant increase in TL and decrease in SDL. The EESC significantly and dose dependently reversed the Sco-induced amnesia. The maximum effect was seen in EESC $(100 \mathrm{mg} / \mathrm{kg})$ treated group. This effect of EESC was comparable to the group treated with Dpl. The group treated with varying doses of AESC showed no significant effect on TL and SDL.

Conclusion: These findings suggested the possible therapeutic potential of EESC $(70 \%)$ for diseases related to memory dysfunctions like dementia in Alzheimer's disease.

Keywords: Scopolamine, Amnesia, Alzheimer's disease, Sida cordifolia L., Transfer latency, Step down latency.

(C) 2017 The Authors. Published by Innovare Academic Sciences Pvt Ltd. This is an open accessarticle under the CC BY license (http://creativecommons. org/licenses/by/4. 0/) DOI: http://dx.doi.org/10.22159/ajpcr.2017.v10s4.21340

\section{INTRODUCTION}

Dementia is considered to be one of the important causes of severe morbidities and mortalities worldwide [1]. It is one of the most prevalent clinical manifestations of Alzheimer's disease (AD). Dementia is due to the loss of cholinergic neurons and innervations in the hippocampus and cerebral cortex region of the brain [2]. It is considered that certain factors like abnormality in the phosphorylation of protein tau, oxidative stress, changes in calcium metabolism, abnormal energy metabolism, neuroinflammation, and abnormal protein processing (unwanted $\mathrm{A} \beta$ generation and accumulation) are considered to be important factors in AD pathology [3]. Neurotransmitter acetylcholine, which is secreted in cortical and hippocampal area of the brain, plays a significant role in the learning and memory process [4]. Agents modulating the activity of acetylcholine can affect learning and memory.

At present, available treatment for dementia includes cholinesterase inhibitors such as tacrine, galantamine, donepezil (Dpl), and rivastigmine which are mostly associated with cholinergic side effects and hepatotoxicity. Another antidementia drug category includes $\mathrm{N}$-methyl-D-aspartate receptor antagonists like memantine which is also associated with lack of neuroprotective activity. Therefore, there is need to find a drug that should have minimum side effects and must exert multiple protective actions, like prevention of neurodegeneration through its antioxidant actions along with cholinergic effects [5].

Various Indian medicinal plants have been reported to be used for thousands of years in the Ayurveda system of medicine for the management of neurodegenerative disorders such as Parkinson's disease, $\mathrm{AD}$, memory loss, neuronal degeneration, and other neural disorders by the Ayurvedic practitioners. As per Ayurvedic pharmacology, medicinal plants have been classified into different groups based on their actions. One of these classes is known as "Rasayana" that mainly includes the antioxidant drugs which act inside the human body by regulating the neuro-immune-endocrine systems [6]. These Rasayana plants are said to strengthen brain, prevent ageing process, rejuvenate cells, prevent diseases, and promote health longevity.

There are several Rasayana plants which have been immensely used for the management of various neurodegenerative diseases, e.g., Mucuna pruriens for the management of Parkinson's disease [7]; Withania somnifera and Melocanna bambusoides for the management of AD [8]. One of such Rasayana plants, Sida cordifolia L. has been selected in this study to evaluate its ameliorative effect on scopolamine (Sco)-induced amnesia model in mice.

S. cordifolia L. (family Malvaceae) is an important medicinal plant of Rasayana group that contains various chemical constituents such as gelatine, asparagine, mucin, ephedrine, vasicine, hypaphorine, vasicinone, potassium nitrate, vasicinol, and phytosterols [9]. This plant is already reported to have significant in vitro and ex vivo antioxidant property [10], anti-inflammatory and lipid lowering activities [11]. Besides, it is reported to be useful in the various nervous disorders such as unilateral paralysis, facial palsy [12], and Parkinson's disease [13-16] as mentioned in the Ayurvedic literature. These related activities reported for this plant suggests the evaluation of this plant for this debilitating condition of dementia. Thus, the objective of current study was to assess the mitigating effect of $S$. cordifolia L. against Sco-induced amnesia model using mice. 


\section{METHODS}

\section{Collection, identification, and authentication of plant}

S. cordifolia L., also known as Bala and Kharenti, was collected in the month of November from Sagar, Madhya Pradesh, India. It was identified and authenticated at Department of Botany, Dr. Hari Singh Gour University, Sagar, Madhya Pradesh, India, and a voucher specimen has been kept in the herbarium of the department (Voucher Specimen No. Bot./Her./5234 dated 03/02/2010 given by Prof. T. R. Sahu).

\section{Preparation of plant extracts}

The fresh whole plant was first washed with water, dried in shade, finely powdered and then passed through sieve $(400 \mu \mathrm{m})$. The powdered material was defatted with petroleum ether at $50^{\circ} \mathrm{C}$ by using Soxhlet apparatus till no oily spot was found on filter paper. Then, the defatted plant material was subjected to extraction with $70 \%$ ethanol using Soxhlet apparatus. This $70 \%$ ethanol extract of S. cordifolia (EESC) was lyophilized and stored at $4^{\circ} \mathrm{C}$ for preliminary pharmacological screening.

Standardized aqueous extract of S. cordifolia (AESC) in the form of dry powder was procured from Amsar Pvt. Ltd., Indore, India. The extract was stored in a tightly closed container at $4^{\circ} \mathrm{C}$ for preliminary pharmacological screening.

\section{Animals}

Female Swiss albino mice aged between 3 and 4 months and weighing 20-30 g were involved for acute toxicity study and Sco-induced amnesia model. The animals were procured from the National Institute of Nutrition, Hyderabad. They were kept in standard animal cages at an ambient temperature. Natural day/night cycles were maintained throughout the study. Food and water was provided ad libitum to animals. Experiments were performed between 09:00 and 16:00 hrs. Before performing the test, animals were kept in the animal room for 1 week and were regularly exposed to the laboratory conditions to acclimatize them to the experimental conditions. Animal experimentation protocol was approved by the Institutional Animal Ethics Committee (379/01/ ab/CPCSEA).

\section{Acute toxicity study}

Organisation for Economic Cooperation and Development (OECD) and Office of Prevention, Pesticides, and Toxic Substances (OPPTS) guidelines (http://www.epa.gov/oppts/home/guideline.htm) were followed with little modification for conducting acute toxicity study. Different groups of three mice received varying doses $(0.5,1.5$ and $2.5 \mathrm{~g} / \mathrm{kg}$; p.o.) of EESC and AESC. Vehicle, i.e., $0.5 \%$ carboxymethyl cellulose (CMC) solution was administered to control group. Rats were observed for the effect on behavior, 30 minutes after the drug administration followed for a total of $72 \mathrm{hrs}$. Observations included tremor, diarrhea, salivation, convulsions, coma, sleep patterns, lethargy, mortality and changes in dermatological, ocular, fur, somatomotor, mucous membranes, circulatory, respiratory, and nervous system [17].

Based on the results of above parameters, varying test doses, i.e., 50,100, and $250 \mathrm{mg} / \mathrm{kg}$; p.o. were calculated for further pharmacological evaluation as per OECD guidelines. The $1 / 50^{\text {th }}, 1 / 25^{\text {th }}$, and $1 / 10^{\text {th }}$ dose of maximum safe dose $(2500 \mathrm{mg} / \mathrm{kg})$ tested in acute toxicity study, corresponding to 50,100 , and $250 \mathrm{mg} / \mathrm{kg}$, were chosen for further pharmacological study.

\section{Sco-induced amnesia model}

The mice ( $\mathrm{n}=6 /$ group) were divided into different groups for employing Sco-induced amnesia model [18,19]. Group 1 (control group) was administered with vehicle, i.e., $0.5 \% \mathrm{CMC}$ solution $(5 \mathrm{~mL} / \mathrm{kg}$; p.o.) for 15 days. Group 2 served as Sco per se treated negative control group and received vehicle for 15 days. Group 3 served as standard per se treated group and was administered with $\mathrm{Dpl}(5 \mathrm{mg} / \mathrm{kg}$; p.o.) for 15 days. Group 4 and 5 served as test per se treated groups and was administered with EESC and AESC (250 mg/kg; p.o.), respectively, for 15 days. Group 6 served as standard treated positive control group and received
Dpl $(5 \mathrm{mg} / \mathrm{kg}$ ) along with Sco. Groups 7-12 served as test treated groups and received EESC and AESC (50,100, $250 \mathrm{mg} / \mathrm{kg})$, respectively, along with Sco. All the treatments were followed for 15 days by p.o. route. On $15^{\text {th }}$ day of treatment, Groups 1,3 , 4, and 5 were administered intraperitoneally (i.p.) with water for injection $(5 \mathrm{~mL} / \mathrm{kg}), 30$ minutes after the vehicle administration. In Groups 2, 6-12, Sco $(0.4 \mathrm{mg} / \mathrm{kg}$, i.p.) was administered, 30 minutes after the last administration of varying treatments (vehicle, Dpl, EESC and AESC) to respective groups on the $15^{\text {th }}$ day. All the groups were introduced to the training session (on the $15^{\text {th }}$ day) after 30 minutes of Sco/water injection for acquisition using different test paradigms, i.e., passive avoidance and elevated plus maze apparatus (EPZ). Retention was observed after 24 hrs, i.e., on $16^{\text {th }}$ day. Solution of the Sco (Acros Organics, Belgium) was prepared in the $0.9 \%$ saline solution. Dpl, EESC, and AESC were suspended in $0.5 \%$ CMC solutions.

\section{Evaluation}

Memory was evaluated by step down latency (SDL) and transfer latency $(\mathrm{TL})$ tests using passive avoidance and EPZ apparatus, respectively.

\section{TL test}

TL is defined as the time (seconds) a mouse takes to move from the open arm to any one of the closed arm with all its four legs inside that arm. TL estimation was done using EPZ apparatus, that served as the significant model, to evaluate the retention of learned tasks by the animals. The procedure, method, and end point for this test were followed using the parameters as described by the earlier evaluators with few modifications $[19,20]$. The EPZ consisted of two closed arms $(16 \mathrm{~cm} \times 5 \mathrm{~cm} \times 12 \mathrm{~cm})$, and two open arms $(16 \mathrm{~cm} \times 5 \mathrm{~cm})$ joined to a central platform having dimensions $5 \mathrm{~cm} \times 5 \mathrm{~cm}$. The maze was raised to a height of $25 \mathrm{~cm}$ above the floor. Then, the mice were given the training session for acquisition by placing them one by one at the central platform, facing toward the open arm and the TL was recorded for them individually. Cutoff time for TL observation was 90 seconds.

Before moving the mouse to their cages, they were kept in the maze for another 2 minutes for exploration of maze. The same procedure was repeated after $24 \mathrm{hrs}$ of the treatment and retention was examined in mice.

\section{SDL test}

The SDL is defined as "the time (in seconds) an animal takes to step down from the raised wooden platform to the grid floor with all its paws on the grid floor." In this test, the passive avoidance behavior of animal was evaluated using SDL method $[19,20]$. The stepdown paradigm apparatus consisted of a rectangular wooden box $(27 \mathrm{~cm} \times 27 \mathrm{~cm} \times 27 \mathrm{~cm})$ with inclusion of Plexiglass wall on one side, a grid floor and a lamp of $15 \mathrm{~W}$ illumination. The grid floor was made up of $3 \mathrm{~mm}$ stainless steel rods placed at a distance of $8 \mathrm{~mm}$ apart and a wooden platform $(10 \mathrm{~cm} \times 7 \mathrm{~cm} \times 1.7 \mathrm{~cm})$ in the center. An isolated stimulator was used to deliver an electric shock of $20 \mathrm{~V}$, AC to the grid floor. Double training sessions were given to the mice for acquisition by placing them individually on the wooden platform and observed for their movements. When the mouse moved with all its four paws on the grid floor, an electric shock was given for 15 seconds and the SDL was recorded. Only those animals were chosen to be continued for the second session and retention test; those showed the SDL in the range of 2-15 seconds. The gap of 90 minutes was kept between the two training sessions. During the second session, an electric shock was repeated for the 15 seconds, if the animal stepped down on the grid floor before the completion of 60 seconds in the apparatus. The animals, who fail to do so in this defined period, they were removed from the apparatus and were further subjected to retention test. Retention (memory) test was done using the same procedure after 24 hrs of the treatment, with the exception of no electric shock applied to the grid. During this test, an upper cutoff time of 300 seconds was set and a significant increase in SDL value was considered as an indication of improvement in memory. 
Statistical analysis

The values were expressed as mean \pm standard error of mean and were analyzed using one-way analysis of variance followed by Tukey Kramer test (Sigma Stat Software, 3.5). In all the tests, the criterion for the statistical significance was set at $\mathrm{p}<0.05$ for all comparisons.

\section{RESULTS}

\section{Acute toxicity study}

The EESC and AESC showed no toxicity at a p.o. dose of $2500 \mathrm{mg} / \mathrm{kg}$ as evidenced by our observations. No mortality or abnormal behavior was observed during the experimental duration. The observations of acute toxicity studies with its pharmacological behavioral screening are shown in Table 1.

The $1 / 50^{\text {th }}, 1 / 25^{\text {th }}$, and $1 / 10^{\text {th }}$ doses of maximum safe dose $(2500 \mathrm{mg} / \mathrm{kg})$ tested in acute toxicity study, i.e., 50,100 , and $250 \mathrm{mg} / \mathrm{kg}$ were selected for further pharmacological study as per OECD guidelines.

\section{Effect on TL}

There was significant $\left(\mathrm{F}_{(11,60)}=28.46, \mathrm{p}<0.001\right)$ change in TL of mice by varying the treatment. The Dpl per se treatment $(13.84 \pm 0.93 ; \mathrm{p}<0.001)$ and EESC $(250 \mathrm{mg} / \mathrm{kg} ; 18.91 \pm 1.14 ; \mathrm{p}<0.05)$ per se treatment showed a significant decrease in TL when compared to the vehicle treated group (23.15 \pm 1.30$)$. However, AESC $(250 \mathrm{mg} / \mathrm{kg})$ per se treatment $(25.03 \pm 1.57)$ showed no significant change in comparision to vehicle control group $(23.15 \pm 1.30)$. Sopolamine treated negative control group showed significant $(41.66 \pm 2.80 ; \mathrm{p}<0.001)$ increase in TL as compared to vehicle control group $(23.15 \pm 1.30)$. The EESC showed decrease in TL of mice at different doses, i.e., 50,100 , and $250 \mathrm{mg} / \mathrm{kg}(\mathrm{p}<0.01, \mathrm{p}<0.001$, and $\mathrm{p}<0.05$, respectively), as compared to negative control group (i.e., Sco per se group). The best effect was seen in $100 \mathrm{mg} / \mathrm{kg}$ of EESC treated group (20.94 \pm 1.27$)$, and this effect was found to be comparable to Dpl treated group (13.84 \pm 0.93$)$. AESC treated groups showed no significant change in TL as compared to the Sco treated negative control group (Fig. 1 and Table 2).

\section{Effect on SDL}

There was significant $\left(\mathrm{F}_{(11,60)}=14.94, \mathrm{p}<0.001\right)$ change in SDL of mice by varying the treatment. The Dpl per se treatment caused significant (226.43 $\pm 15.22 ; \mathrm{p}<0.001)$ increase in SDL when compared to vehicle control group (154.06 \pm 8.69$)$. However, no significant effect was seen on SDL by EESC $(202.93 \pm 12.32)$ and AESC $(149.24 \pm 9.41)$ at $250 \mathrm{mg} / \mathrm{kg}$ per se treatment, as compared to vehicle per se treated group (154.06 \pm 8.69$)$. Sco per se treated group showed significant $(104.01 \pm 6.99 ; p<0.01)$ decrease in SDL when compared to vehicle control group (154.06 \pm 8.69$)$. The EESC showed increase in SDL of mice at $50 \mathrm{mg} / \mathrm{kg}(141.66 \pm 8.61)$ and $100 \mathrm{mg} / \mathrm{kg}(160.45 \pm 9.74)$ dose $(\mathrm{p}<0.05$ and $\mathrm{p}<0.001$ significance level respectively), when compared to Sco treated negative control group $(104.01 \pm 6.99)$. The best effect was seen in $100 \mathrm{mg} / \mathrm{kg}$ of EESC treated group (160.45 \pm 9.74$)$, and this effect was comparable to Dpl treated group $(226.43 \pm 15.22)$. The increase in SDL of mice was not significant at $250 \mathrm{mg} / \mathrm{kg}$ dose of EESC (130.57 \pm 9.80$)$, when compared to Sco per se treated group $(104.01 \pm 6.99)$. Varying doses of AESC did not show a significant change in SDL when compared to Sco per se treated group (Fig. 2 and Table 2).

\section{DISCUSSION}

Previous studies have shown low toxic profile of $S$. cordifolia in different studies. Franzotte et al., (2000) reported low acute toxicity of AESC leaves in mice [21]. Rao and Mishra reported that the lethal dose $50 \%\left(\mathrm{LD}_{50}\right)$ value for $S$. cordifolia was higher than $10 \mathrm{~g} / \mathrm{kg}$ in rats [22]. High i.p. doses of hydroalcoholic extract of its leaves was reported to be toxic. $L_{50}$ value was found to be $2639 \mathrm{mg} / \mathrm{kg}$ b.w. However, oral administration of the extract was found to be safe [23]. Asdaq et al. also reported that methanolic extract of this plant was safe up to $5 \mathrm{~g} / \mathrm{kg}$ dose [24]. The aqueous plant infusions were found to be safe when tested in cytotoxicity study on PC12 cell line using 3-(4,5-dimethylthiazol-2-yl)-2,5-diphenyltetrazolium bromide test [10]. In our study, EESC and AESC showed no toxicity at tested dose of $2500 \mathrm{mg} / \mathrm{kg}$. The low toxic profile of EESC and AESC was in accordance with the previous reported studies.

In Sco-induced amnesia model, EESC significantly reversed the Sco induced amnesia in both TL and SDL tests, whereas AESC failed to show any reversal of Sco-induced amnesia. The TL test is a neutral behavioral model which is being used to evaluate learning and memory in animals $[18,19,25]$. TL test principle is based on the supposition that mice prefer the closed arms over the open arms [26]. The SDL test is useful in measurement of acquisition, memory retention, and retrieval process [27].

The cholinergic system in the hippocampus and cerebral cortex plays an indispensible role in learning and memory process [28]. Deficit in cholinergic system may lead to the cognitive impairments symptoms observed in AD [29]. Sco is a well-known nonselective muscarinic receptor blocker that induces deterioration of learning and memory process in animals $[18,19]$. Sco-induced amnesia model is an interoceptive behavioral model which is widely cited in the literature for mimicking human dementia [18,19,25,29]. Transient memory impairment is observed shortly after Sco administration. The benefit of

Table 1: Pharmacological behavioral screening along with acute toxicity studies of EESC and AESC

\begin{tabular}{|c|c|c|c|c|c|c|c|}
\hline \multirow[t]{3}{*}{ Observations } & \multicolumn{7}{|l|}{ Inference } \\
\hline & \multirow{2}{*}{$\begin{array}{l}\text { Control } \\
5 \mathrm{~mL} / \mathrm{kg}\end{array}$} & \multicolumn{3}{|l|}{ EESC } & \multicolumn{3}{|l|}{ AESC } \\
\hline & & $0.5 \mathrm{~g} / \mathrm{kg}$ & $1.5 \mathrm{~g} / \mathrm{kg}$ & $2.5 \mathrm{~g} / \mathrm{kg}$ & $0.5 \mathrm{~g} / \mathrm{kg}$ & $1.5 \mathrm{~g} / \mathrm{kg}$ & $2.5 \mathrm{~g} / \mathrm{kg}$ \\
\hline Mortality & - & - & - & - & - & - & - \\
\hline Coma & - & - & - & - & - & - & - \\
\hline Changes in skin and fur & - & - & - & - & - & - & - \\
\hline Changes in eyes & - & - & - & - & - & - & - \\
\hline Changes in mucous membranes & - & - & - & - & - & - & - \\
\hline Changes in respiratory system & - & - & - & - & - & - & - \\
\hline Changes in circulatory system & - & - & - & - & - & - & - \\
\hline Changes in autonomic nervous system activity & - & - & - & - & - & - & - \\
\hline Changes in CNS activity & - & - & - & - & - & - & - \\
\hline Changes in somatomotor activity & - & - & - & - & - & - & - \\
\hline Tremors & - & - & - & - & - & - & - \\
\hline Diarrhea & - & - & - & - & - & - & - \\
\hline Salivation & - & - & - & - & - & - & - \\
\hline Sleep & - & - & - & - & - & - & - \\
\hline Lethargy & - & - & - & - & - & - & - \\
\hline
\end{tabular}

-: Absence of activity, EESC: Ethanolic extracts of Sida cordifolia, AESC: Aqueous extracts of Sida cordifolia, CNS: Central nervous system 


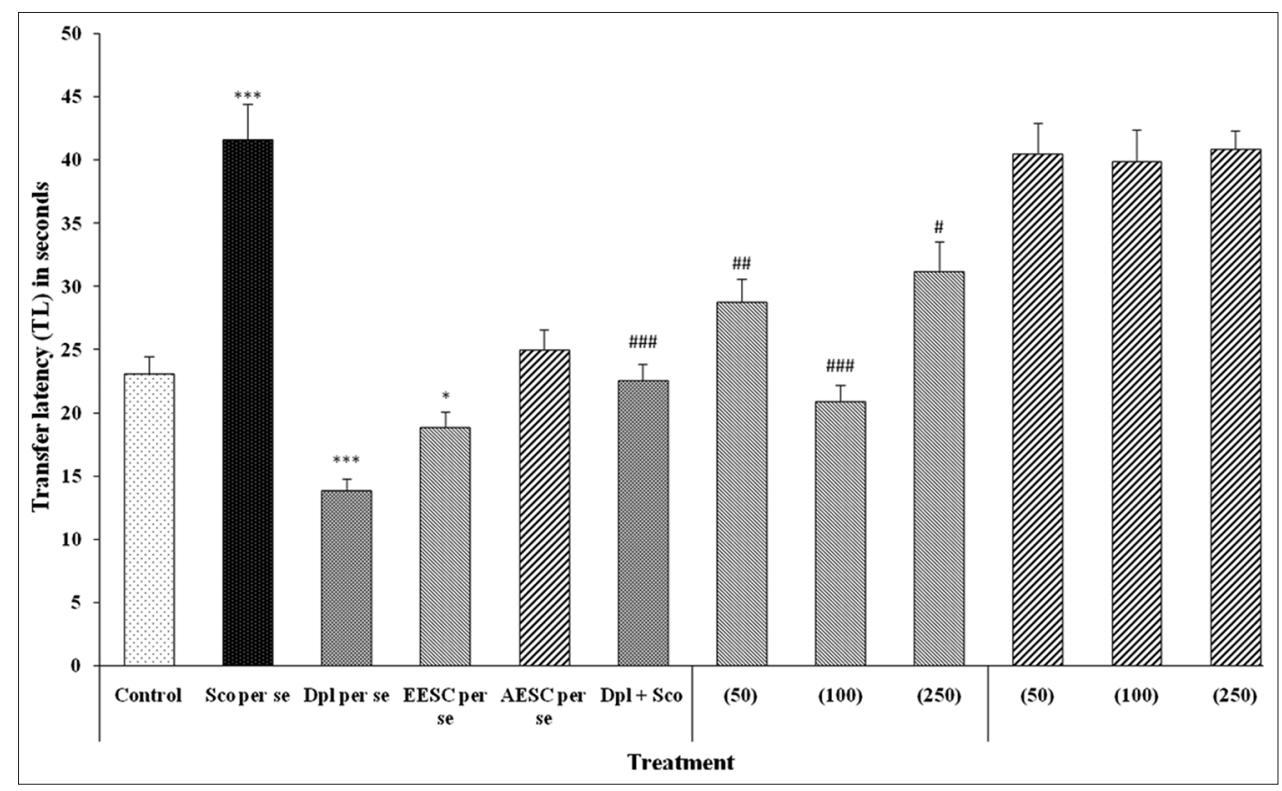

Fig. 1: Effect of varying doses of ethanolic extracts of Sida cordifolia - EESC, aqueous extracts of Sida cordifolia - AESC and donepezil (Dpl) on transfer latency of scopolamine (Sco) treated mice. ${ }^{*}$ Represents $\mathbf{p}<0.05$, ${ }^{* * *}$ represents $\mathbf{p}<0.001$ significant, when compared to vehicle per se treated control group; " represents p<0.05, "\#"represents $\mathbf{p}<0.01$, ${ }^{\# \# \#}$ represents $\mathbf{p}<0.001$ significant, when compared to scopolamine (Sco) per se treated group

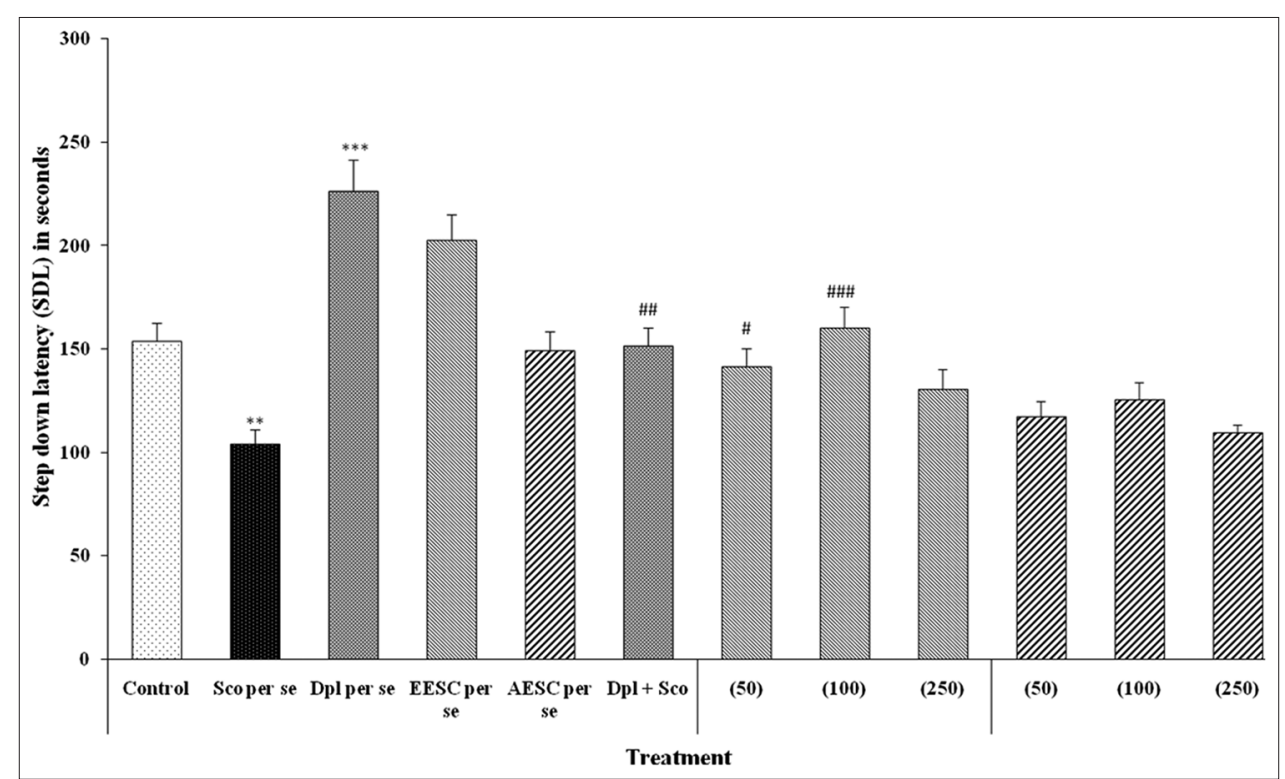

Fig. 2: Effect of varying doses of ethanolic extracts of Sida cordifolia - EESC, aqueous extracts of Sida cordifolia - AESC and donepezil (Dpl) on step down latency of scopolamine (Sco) treated mice. ${ }^{* *}$ Represents $\mathbf{p}<0.01,{ }^{* * *}$ represents $\mathbf{p}<0.001$ significant, when compared to vehicle per se treated control group; " represents $\mathbf{p}<0.05$, "\#\#represents $\mathbf{p}<0.01$, \#\#" represents $\mathbf{p}<0.001$ significant, when compared to scopolamine (Sco) per se treated group

various cholinergic agonists is now well established to cause reversal of Sco-induced amnesic effects in animals as well as humans. Sco-induced amnesia model has been used extensively to screen various potential antidementia drugs $[18,19,30-32]$.

Learning and memory was significantly impaired by Sco treatment, as observed by increase in TL and decrease in SDL in respective tests. A consecutive 15 days treatment with EESC at 50,100, and $250 \mathrm{mg} / \mathrm{kg}$ ) attenuated the effect of Sco-induced learning and memory impairment of mice. $100 \mathrm{mg} / \mathrm{kg}$ dose of EESC showed the best effect, and this was comparable to Dpl treatment. These outcomes of the study open the scope of possible utility of the EESC for various cognitive dysfunctions.
It also suggested the benefit of EESC for modulating cholinergic transmission in central nervous system (CNS) by its possible neuroprotective effect.

There is dose-dependent effect of EESC on memory. It showed inverse U-shaped dose-response effect which is a typical characteristic of drugs acting on memory and anxiety state $[18,19,33,34]$. This effect can be attributed to the dose dependent modulation of cholinergic transmission in CNS which is responsible for cognition.

The AESC treatment failed to show a significant effect in the present memory model. The observed ameliorative effect by EESC over 
Table 2: Effect of varying doses of extracts on SDL and TL of mice

\begin{tabular}{lll}
\hline Treatment group & TL (in seconds) & SDL (in seconds) \\
\hline Control & $23.15 \pm 1.30$ & $154.06 \pm 8.69$ \\
Sco per se & $41.66 \pm 2.80^{* * *}$ & $104.01 \pm 6.99^{* *}$ \\
Dpl per se & $13.84 \pm 0.93^{* * *}$ & $226.43 \pm 15.22^{* * *}$ \\
EESC $(250 \mathrm{mg} / \mathrm{kg})$ per se & $18.91 \pm 1.14^{*}$ & $202.93 \pm 12.32$ \\
AESC $(250 \mathrm{mg} / \mathrm{kg})$ per se & $25.03 \pm 1.57$ & $149.24 \pm 9.41$ \\
D pl+Sco & $22.59 \pm 1.27^{\# \# \#}$ & $151.71 \pm 8.57^{\# \#}$ \\
EESC $(50 \mathrm{mg} / \mathrm{kg})+$ Sco & $28.82 \pm 1.75^{\# \#}$ & $141.66 \pm 8.61^{\#}$ \\
EESC $(100 \mathrm{mg} / \mathrm{kg})+$ Sco & $20.94 \pm 1.27^{\# \# \#}$ & $160.45 \pm 9.74^{\# \# \#}$ \\
EESC $(250 \mathrm{mg} / \mathrm{kg})+$ Sco & $31.18 \pm 2.34 \#$ & $130.57 \pm 9.80$ \\
AESC $(50 \mathrm{mg} / \mathrm{kg})+$ Sco & $40.53 \pm 2.39$ & $117.60 \pm 6.94$ \\
AESC $(100 \mathrm{mg} / \mathrm{kg})+$ Sco & $39.91 \pm 2.51$ & $125.82 \pm 7.93$ \\
AESC $(250 \mathrm{mg} / \mathrm{kg})+$ Sco & $40.93 \pm 1.42$ & $109.65 \pm 3.80$ \\
\hline
\end{tabular}

${ }^{*}$ Represents $\mathrm{p}<0.05,{ }^{* *}$ represents $\mathrm{p}<0.01,{ }^{* * *}$ represents $\mathrm{p}<0.001$ significant, when compared to vehicle per se treated control group; "represents $\mathrm{p}<0.05$, \#\#represents $\mathrm{p}<0.01$, \#\#\#represents $\mathrm{p}<0.001$ significant, when compared to Sco per se treated group. Sco: Scopolamine, Dpl: Donepezil, EESC: Ethanolic extracts of Sida cordifolia, AESC: Aqueous extracts of Sida cordifolia

AESC in this model might be due to the presence of some specific phytoconstituents present in EESC, which could be responsible for its beneficial effect. It is reported to contain number of important phytoconstituents having significant neuropharmacological importance, e.g., $\beta$-sitosterol, ephedrine, phenethylamine, choline, betaine, asparagine, hypaphorine, vasicinone, vasicine, vasicinol, sidasterone A, and sidasterone B [9].

\section{CONCLUSION}

Pharmacological screening of plant extracts (EESC and AESC) for Sco-induced amnesia model showed significant ameliorative effect of EESC over AESC, as observed by the behavioral studies using TL and SDL paradigms. This ameliorative effect can be attributed to its antioxidant effect, acetylcholinesterase inhibition, and/or increase in cholinergic transmission by the EESC, which should be further explored. It may be concluded from the findings of this study that EESC has a good therapeutic potential for diseases associated with memory dysfunctions like in AD. This work is our small step to enlighten the path of developing newer and more effective therapeutic leads for this debilitating condition, having national as well as worldwide interest.

\section{ACKNOWLEDGMENTS}

The authors are grateful to CSIR, Government of India, for providing the financial assistance to Mr. Navneet Khurana for this project. Authors are also thankful to Amsar Pvt. Ltd., Indore, India, for providing the gift sample of S. cordifolia L. extract.

\section{REFERENCES}

1. McCarty MF. Toward prevention of Alzheimers disease-potential nutraceutical strategies for suppressing the production of amyloid beta peptides. Med Hypotheses 2006;67(4):682-97.

2. Korczyn AD, Vakhapova V. The prevention of the dementia epidemic. J Neurol Sci 2007;257:2-4.

3. Ferreira A, Proença C, Serralheiro ML, Araújo ME. The in vitro screening for acetylcholinesterase inhibition and antioxidant activity of medicinal plants from Portugal. J Ethnopharmacol 2006;108(1):31-7.

4. Ellis JM. Cholinesterase inhibitors in the treatment of dementia. J Am Osteopath Assoc 2005;105(3):145-58.

5. Rang HP, Dale MM, Ritter JM, Flower RJ, Henderson G. Rang and Dale's Pharmacology. $7^{\text {th }}$ ed. London: Elsevier; 2012.

6. Arun Raj GR, Shailaja U, Debnath P, Banerjee S, Rao PN. Exploratory studies on the therapeutic effects of kumarabharana rasa in the management of chronic tonsillitis among children at a tertiary care hospital of Karnataka. J Tradit Complement Med 2015;6(1):29-33.

7. Vaidya AB, Rajagopalan TG, Mankodi NA, Antarkar DS, Tathed PS, Purohit AV, et al. Treatment of Parkinson's disease with the cowhage plant-Mucuna pruriens Bak. Neurol India 1978;26(4):171-6.
8. Bhattacharya SK, Kumar A, Ghosal S. Effects of glycowithanolides from Withania somnifera on an animal model of Alzheimer's disease and perturbed central cholinergic markers of cognition in rats. Phyther Res 1995;9(2):110-3

9. Pattar PV, Jayaraj M. Pharmacognostic and phytochemical investigation of Sida cordifolia L. A threatened medicinal herb. Int J Pharm Pharm Sci 2012;4(1):114-7.

10. Auddy B, Ferreira M, Blasina F, Lafon L, Arredondo F, Dajas F, et al. Screening of antioxidant activity of three Indian medicinal plants, traditionally used for the management of neurodegenerative diseases. J Ethnopharmacol 2003;84:131-8.

11. Swathy SS, Panicker S, Nithya RS, Anuja MM, Rejitha S, Indira M. Antiperoxidative and antiinflammatory effect of Sida cordifolia Linn. On quinolinic acid induced neurotoxicity. Neurochem Res 2010;35(9):1361-7.

12. Rastogi R, Malhotra B. Compendium of Indian Medicinal Plants. $4^{\text {th }}$ ed; 1985. Available from: http://www.vedicbooks.net/compendiumindian-medicinal-plants-volumes-p-13632.html. [Last accessed on 2017 Mar 29].

13. Nagashayana N, Sankarankutty $P$, Nampoothiri MR, Mohan PK, Mohanakumar KP. Association of L-DOPA with recovery following Ayurveda medication in Parkinson's disease. J Neurol Sci 2000;176(2):124-7.

14. Khurana N, Sharma N, Patil S, Gajbhiye A. Phyto-pharmacological properties of Sida cordifolia: A review of folklore use and pharmacological activities. Asian J Pharm Clin Res 2016;9(14):52.

15. Khurana N, Gajbhiye A. Ameliorative effect of Sida cordifolia in rotenone induced oxidative stress model of Parkinson's disease. Neurotoxicology 2013;39:57-64.

16. Khurana N, Jain PK, Pounikar Y, Shailendra P, Gajbhiye A. Reversal of reserpine-induced orofacial dyskinesia and catalepsy by Sida cordifolia. Int J Pharmacol Pharm Technol 2012;1(2):121-5.

17. Lorke D. A new approach to practical acute toxicity testing. Arch Toxicol 1983;54(4):275-87.

18. Habibyar AF, Sharma N, Khurana N. PASS assisted prediction and pharmacological evaluation of hesperidin against scopolamine induced amnesia in mice. Eur J Pharmacol 2016;789:385-94.

19. Khurana N, Ishar MP, Gajbhiye A, Goel RK. PASS assisted prediction and pharmacological evaluation of novel nicotinic analogs for nootropic activity in mice. Eur J Pharmacol 2011;662:22-30.

20. Vasudevan M, Parle M. Memory enhancing activity of Anwala churna (Emblica officinalis Gaertn.): An Ayurvedic preparation. Physiol Behav 2007;91(1):46-54.

21. Franzotti EM, Santos CV, Rodrigues HM, Mourão RH, Andrade MR, Antoniolli AR. Anti-inflammatory, analgesic activity and acute toxicity of Sida cordifolia L. (Malva-branca). J Ethnopharmacol 2000;72:273-7.

22. Rao K, Mishra S. Antihepatotoxic activity of Sida cordifolia whole plant. Fitoterapia 1998;69(1):20-3.

23. Franco CI, Morais LC, Quintans-Júnior LJ, Almeida RN, Antoniolli AR. CNS pharmacological effects of the hydroalcoholic extract of Sida cordifolia L. leaves. J Ethnopharmacol 2005;98(3):275-9.

24. Asdaq SM, Nayeem N, Das AK. Effect of hydroalcholic extracts of Sida cordifolia L. on lipid profile in rats. Pharmacol Online 2008;3:227-39.

25. Dhingra D, Parle M, Kulkarni SK. Memory enhancing activity of Glycyrrhiza glabra in mice. J Ethnopharmacol 2004;91:361-5.

26. Itoh J, Nabeshima T, Kameyama T. Utility of an elevated plusmaze for the evaluation of memory in mice: Effects of nootropics, scopolamine and electroconvulsive shock. Psychopharmacology (Berl) 1990;101(1):27-33.

27. Luo J, Yin JH, Wu HZ, Wei Q. Extract from fructus cannabis activating calcineurin improved learning and memory in mice with chemical drug-induced dysmnesia. Acta Pharmacol Sin 2003;24(11):1137-42.

28. Giovannini MG, Casamenti F, Bartolini L, Pepeu G. The brain cholinergic system as a target of cognition enhancers. Behav Brain Res 1997;83:1-5

29. Huff FJ, Mickel SF, Corkin S, Growdon JH. Cognitive functions affected by scopolamine in Alzheimer's disease and normal aging. Drug Dev Res 1988;9:12271-8

30. Kanwal A, Mehla J, Kuncha M, Ganga V, Naidu M, Gupta YK, et al. Anti-amnesic activity of Vitex negundo in scopolamine induced amnesia in rats. Pharmacol Pharm 2010;14236:1-8.

31. Mishima K, Tsukikawa H, Miura I, Inada K, Abe K, Matsumoto Y, et al. Ameliorative effect of NC-1900, a new AVP4-9 analog, through vasopressin V1A receptor on scopolamine-induced impairments of spatial memory in the eight-arm radial maze. Neuropharmacology 2003;44(4):541-2. 
32. Rubaj A, Zgodzinski W, Sieklucka-Dziuba M. The influence of adenosine A3 receptor agonist: IB-MECA, on scopolamine- and MK801-induced memory impairment. Behav Brain Res 2003;141(1):11-7.

33. Shete RV, Bodhankar SL. Neuropharmacology of ethanolic extract of
Hemidesmus indicus. Electron J Pharmacol Ther 2009;2:63-70.

34. Une HD, Sarveiya VP, Pal SC, Kasture VS, Kasture SB. Nootropic and anxiolytic activity of saponins of Albizzia lebbeck leaves. Pharmacol Biochem Behav 2001;69:439-4. 